JA: Jurnal A1-Wasath 2 No.1: 1-7

Journal homepage: https://journal.unusia.ac.id/index.php/alwasath/index

ISSN 2721-6160 (Online)

\section{Hukum dan Moral: Mengulik Ulang Perdebatan Positivisme \\ Hukum dan Teori Hukum Kodrat H.L.A Hart \& Lon F. Fuller}

\section{Muhammad Rusydi DR}

Tenaga Ahli DPR-RI

\begin{abstract}
Abstrak
Tulisan ini mengulas kembali secara deskriptif pertukaran pendapat antara dua teoritikus hukum yang cukup berpengaruh dalam Ilmu Hukum: H.L.A. Hart dan Lon F. Fuller. Tokoh yang pertama merupakan salah satu pemikir dari madzhab positifisme hukum, sementara yang kedua lebih dekat kepada teori hukum alam atau hukum kodrat. Perdebatan antara keduanya dalam tulisan ini merujuk kepada dua teks awal perdebatan keduanya, yaitu "Positivism and the Separation of Law and Morals" dari Hart dan "Positivism and Fidelity to Law-A Reply to Professor Hart" dari Lon Fuller dimana keduanya terbit pada tahun yang sama, 1958.
\end{abstract}

\section{Keywords:}

Postivisme Hukum, Teori Hukum Alam, H.L.A. Hart, Lon F. Fuller.

\section{Corresponding Author:}

Muhammad Rusydi DR

Tenaga Ahli DPR-RI

E-mail: muhammadrusydidr@gmail.com

(C) The Author(s) 2021

DOI: 10.47776/alwasath.v2i1.134

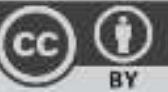

CC BY: This license allows reusers to distribute, remix, adapt, and build upon the material in any medium or format, so long as attribution is given to the creator. The license allows for commercial use.
Submitted: 27 Februari 2021

Accepted: 21 April 2021

Online: 21 April 2021

\section{Classification}

Conceptual Article

(1)




\section{PENDAHULUAN}

Perdebatan perspektif dalam Ilmu Hukum sangatlah menarik. Hal ini terlihat dari banyaknya pemikiran-pemikiran para pemikir hukum yang terus berkontestasi agumen khususnya mengenai hukum, penerapan, hingga tujuan dari hukum tersebut. Kontestasi pemikiran ini kemudian tertuang dan menjadi landasan para pemikir-pemikir selanjutnya dalam memahami hukum. Perdebatan demi perdebatan terus bergeliat hingga memunculkan aliran-aliran pemikiran bagi keilmuan Hukum itu sendiri.

\section{HASIL DAN PEMBAHASAN}

Salah satu perdebatan yang sangat menarik dalam keilmuan Hukum hingga saat ini adalah Perdebatan antara H.L.A Hart dan Lon Fuller. Perdebatan antara mereka dapat dikatakan sebagai perdebatan paling menarik dalam abad ke-21. Kedua pemikir ini memberikan gambaran mengenai pemaknaan hukum pada konteks Hukum yang sebenarnya. Tulisan ini akan menguraikan dengan sangat sederhana mengenai perdebatan diantara kedua pemikir besar tersebut.

Pemikiran kedua pemikir ini lebih kepada bagaimana Hukum yang di fahami didasari pada dua filsafat yang berbeda. Dimana Positivisme hukum dan Hukum Alam mengambil peran dalam memandang hukum. Positivisme hukum ini dikemukakan oleh H.L.A Hart sedangkan Hukum alam dikemukakan oleh Lon Fuller, kedua pemikir ini dinobatkan sebagai pemikir yang produktif dan merupakan pentolan dari kedua filsafat hukum tersebut meskipun mereka bukan orang yang pertama sekali memperkenalkan pemahaman ini.

Sebenarnya Positivisme Hukum merupakan aliran yang bersifat Yudisprudensi analitis. Artinya, filsafat ini mencoba memaknai arti penting dari Apa itu Hukum. Meskipun banyak pemikir yang beranggapan Yudisprudensi analitis ini semakin kabur pemaknaanya, namum belum ada pemikir yang mampu menjelaskan sejauh mana filsafat ini kabur dari tujuan asalnya. Filsafat jenis ini dikembangkan oleh pemikir hukum pada abad ke-18 dan 19 seperti Jeremy Bentham dan juga John Austin. Sedangkan Hukum alam adalah jenis filsafat yang menitikberatkan pada hak kodrat manusia.

Sejarah hukum alam tidak terepas dari adanya pemkikiran penggunaan akal manusia yang akan bermanfaat bagi banyak orang. ${ }^{1}$ Keterkaitannya dengan hukum adalah Hukum merupakan produk akal manusia yang harus bisa dimanafaatkan oleh manusia dan berguna bagi manusia untuk mencapai hak kodrat manusia itu sendiri. Moralitas adalah salah satu kodrat yang diberikan oleh Allah kepada manusia dan itu telah di tungaskan di banyak kitabkitab suci seperti perjanjian lama dan Baru serta sebelumnya pada kitab-kitab Yunani kuno. ${ }^{2}$ Bahkan di beberapa buku di sebut juga sebagai filsafat Romawi kuno, dikarenakan filsafat ini banyak secara simultan muncul di berbagai negara.

Pemikiran ini didasari pada adanya penentangan terhadap Gejera dan Agama Kristen yang digunakan sebagai alat kekuasaan dan penindasan atasnama Agama. Banyak pemikir saat itu telah menggunakan akal sebagai salah satu rujukan berfikir yang saat itu telah dibutakan oleh Kristen. Penentangan ini didasari adanya perlakuan amoral dari pemimpin Kerajaan dan Kristen dalam menguasai sumber daya alam dan sumber daya manusia termasuk kehidupan sosial, Pajak, dan penebusan dosa yang tidak beraturan dan bertetantanagan dengan ajaran yang ada. Kristen menjadi satu ide yang salah, Gereja menjadi institusi yang jahat dan kerajaan adalah penguasa bagi Kristen dan Gereja yang berujung pada tidak berlakunya kehidupan sosial yang baik pada masa itu.

Kedua filsafat ini kemudian, antara Positivisme Hukum dan Hukum alam menjadi salah satu pemikiran Hukum yang besar dan paling berpengaruh. Pada pembahasan ini

1 Strauss, Leo, 1968, “Natural Law” Encyclopedia of the Social Sciences, Macmillan.

${ }^{2}$ Rommen, Heirinc A, 1947, "The Natural Law: A Study in Legal and Social Philosophy Trans" 
perdebatan ini didasari pada sebuah fenomena sosial besar di masa lalu. Terdapat anomali yang tampak jelas mengenai hukum yang masing-masing dasar pemikiran besar tersebut terhiraukan oleh fenomena tersebut.

Namun sebelumnya, perlu difahami dasar pemikiran dan konteks awal lahirnya perdebatan antara H.L.A Hart dan Lon Fuller adalah mengenai penerapan Hukum di masa Perang dunia kedua. Pada masa itu Nazi Jerman memiliki sistem hukum yang tersendiri dan dianggap penerapannya sangat keji dan tidak manusiawi dikalangan negara-negara lain. Nazi menerapkan sistem dengan dasar Fasisme dan Nasionalisme, dimana Hukum di dasarkan pada semangat Kebangsaan Aria dan Nasionalisme Fasis ala Nazi.

Semua hukum dilakukan untuk kepentingan nasional Nazi meskipun dalam hukum tersebut banyak terdapat hukuman yang hirau akan kemanusiaan; pembunuhan, kerja paksa, menawan tawanan perang, penyiksaan, pembakaran, hingga pemusnahan etnis atau orang yang dianggap berkhianat dan bukan bagian dari Bangsa Aria Nazi, serta orang yang tidak mau tunduk dan patuh dengan kepentingan Nasional Nazi.

Pada fenomena tersebut, Hart berpendapat bahwa tindakan-tindakan ini meskipun dianggap tidak manusiawi adalah sah menurut hukum. ${ }^{3}$ Penjelasan ini lebih rinci dijelaskan Hart karena otoritas hukum haruslah di buat oleh otoritas tertinggi di suatu wilayah, kemurnian hukum juga akan muncul jika otoritas tersebut tidak tercampur dengan otoritasotoritas lainnya baik yang tampak jelas maupun secara abstrak dan hidup pada dunia kolektifitas masyarakatnya (Moralitas).

Bagi Hart, hukum memiliki kedaulatan hukum negara atau wilayah dimana sebuah sistem berlaku pada wilayah dan sistem hukum negara tersebut. Karena pada dasarnya, Hukum adalah ketetapan yang ketika seseorang telah berada pada zona hukum suatu negara berarti telah berkomitmen pada sistem dan hukum yang berlaku di wilayah tersebut. Hal ini menjadi salah satu cara negara bisa menerapkan hukum dan kedualatannya tanpa harus menerima pandangan dan intervensi negara dan hukum asing dari luar wilayah negara tersebut.

Tanpa menomorduakan aspek-aspek lain, satu-satunya cara agar pelaku atau pelanggar hukum bisa ditindak secara hukum adalah melalui Undang-Undang yang ada. Undnag-Undang merupakan produk yang telah lahir dengan kesepakatan yang sama dan dengan kesamaan posisi bagi semua masyarakat. Tidak ada satu unsurpun yang boleh merubah hukum demi terlaksananya hukum murni di suatu wilayah. Kemurnian hukum adalah ketika pelaksanaanya tidak tergantung pada situasi dan keadaan yang mampu mengintervensi kekuatan dan wibawa hukum.

Menurut Hart, hukum itu sesuai dengan apa yang seharusnya menjadi hukum itu sendiri. ${ }^{4}$ Mempertahankan aspek lain selain hukum tidak hanya dapat menjadi masalah buruk secara intelektual, tetapi juga dapat mendorong individu atau masyarakat untuk mempertanyakan atau bahkan menolak untuk mematuhi sebuah Hukum. Pada hakikatnya hukum tidak bermoral, ${ }^{5}$ dan tidak ada moralitas dalam hukum, bagi Hart.

Hukum yag didekatkan dengan moral akan cenderung membawa hukum pada tujuan yang buruk. Keberadaan Hukum yang dalam penegakannya selalu tertahan dengan moralitas bisa meningkatakan semangat individu atau masyarakat untuk mematuhi secara membabibuta dan hanya dipakai untuk tujuan-tujuan yang tidak bermoral.

${ }^{3}$ Hart, H. L. A, 1958, "Positivism and the Separation of Law and Morals", Harvard Law Review, 71 (4): 593-629.

${ }^{4}$ Hart, H. L. A, (1958), Positivism and the Separation of Law and Morals, Harvard Law Review, 71 (4): 593-629.

${ }^{5}$ Hart, H. L. A, ibid, 593-629. 
Keberadaan moral bisa menjadi alat penguasa atau sekelompok orang untuk bisa lepas dari hukum. Moral yang dijadikan alat untuk memerangi hukum pada dasarnya adalah sebagai alat untuk memerangi moral tersebut, dengan memberi dalil-dalil yang secara tidak langsung menjatuhkan wibawa dan kedaulatan Hukum. Sehingga memunculkan pemahaman jika Hukum haruslah dipisahkan dari segala bentuk aspek-aspek di luar hukum, termasuk moral.

Melihat teori hukum ini, Hart melihat bahwasanya moralitas yang dianggap sebagai Hukum akan memiliki nilai yang berbeda diantara pemimpin pemerintah yang satu dengan yang lainnya khususnya dalam penegakan hukum. ${ }^{6}$ Akan terjadi kerusakan hukum yang besar, dimana validasai hukum akan kalah dengan perspektif pemimpin yang akan menegakkan hukum. Hukum haruslah sesuai fakta hukum, sedangkan moralitas hanya sebagai norma yang hanya diakui dikalangan masyarakat dan bukan bagian dari penegakan hukum karena tidak tertulis dan dikodifikasi sebagai aturan menjadi sebuah Undag-Undang.

Pandangan ini kemudian dibantah dengan perspektif Lon Fuller. Fuller memiliki argumentasi lain mengenai sistem, hukum dan penegakannya. Bagi Fuller, Hart terlalu cepat mengakui bahwa tindakan tidak manusiawi atas dasar hukum itu sah dan diperbolehkan. Menjadi catatan penting dalam argumentasi Fuller adalah untuk mencapai tujuan hukum yang baik tidaklah dengan melalui hukum yang benar. ${ }^{7}$ Pada argumentasi ini Fuller berpendapat jika Nazi Jerman memiliki tujuan yang tidak bermoral dan manusiawi, justru hukum yang berlaku di Nazi Jerman dipergunakan untuk tujuan-tujuan yang tidak bermoral.

Fuller menekankan pada pentingnya keberadaan sistem hukum yang memungkinkan manusia untuk mengatur interaksi mereka satu sama lain dengan mengacu pada aturan. Sehingga kemanusiaan bisa terjalin dengan baik yang berujung pada padunya antara Hukum dan Moralitas yang digunakan dengan cara yang benar dan sah. Hukum yang dimaksud Fuller adalah Hukum publik yang jelas, tidak kotradiktif, proskriptif, dapat diandalkan, mungkin untuk mematuhi, dan diterapkan sebagai Hukum yang seharusnya dijalankan. ${ }^{8}$

Bagi Fuller penyimpangan prosedur sistemik di mana Nazi sangat melanggar prinsipprinsip hukum yang bertujuan pada penerapan kemanusiaan dan moralitas. ${ }^{9}$ Prinsip yang dimaksud adalah prinsip moralitas yang mana menurut Fuller tujuan hukum adalah mencapai tingkat moralitas yang tinggi. Sangat tidak mungkin moral lahir dari sistem hukum yang tidak melihat pada sisi moral malah memisahkan diri dari moral itu sendiri.

Karena pada kenyataanya, arguemantasi Fuller menunjukkan bahwa keberadaan Hukum Nazi secara sepihak dapat dikatakan sebagai hukum yang ilegal. Argumen ini dia bangun karena pada sistem Nazi terdapat penyimpangan termasuk penggunaan secara luas atas Undang-Undang untuk tindakan yang tidak bermoral termasuk pembunuhan massal yang sah, peraturan dan perundang-undangan rahasia, dan campur tangan politik dengan lembaga peradilan yang sedemikian rupa sehingga interpretasi dan penerapan Hukum menjadi tunduk pada keinginan pemimpin tanpa ada dasar Hukum yang baik dan benar.

Mengingat penyimpangan ini, Fuller pasca pengadilan Nazi dapat secara sah menolak untuk menghindari akibat hukum atas tindakan tidak manusiawi yang dilakukan di bawah warna "hukum" Nazi. ${ }^{10}$ ktidakmanusiawian itu menjadi dasar yang dapat digunakan untuk menolak semua dalil-dalil hukum dan penerapan yang ada di Nazi. Ketidakmanusiawiaan itu lantas merupakan bentuk hukum paling buruk yang ada karena sama sekali tidak

\footnotetext{
${ }^{6}$ Hart, H. L. A, ibid, 593-629.

${ }^{7}$ Fuller, Lon L, 1958, Positivism and Fidelity to Law-A Reply to Professor Hart, Harvard Law Review. 71

${ }^{8}$ Fuller, Lon L, ibid, 630-672

${ }^{9}$ Fuller, Lon L, ibid, 630-672.

${ }^{10}$ Fuller, Lon L, ibid, 630-672
} (4): 630-672. 
mencerinkan nilai hukum yang murni dan mencerminkan mengapa hukum itu di buat dan mengapa hukum itu ada.

Pendapat Fuller ini terkait dengan teori hukum umumnya, menurutnya sistem hukum tidak didasari oleh pada perspektif pemimpin secara internal belaka dan tentang apa yang dianggap sebagai perangkat hukum yang sah, melainkan oleh orientasi yang dibagikan oleh para pejabat dan subjek hukum yang sama-sama mengatur interaksi mereka satu sama lain dengan cara yang menampilkan kesetiaan pada prinsip-prinsip legalitas. Fuller menyebutnya sebagai moralitas internal hukum. ${ }^{11}$ Pada akhirnya antitesis yang ditawarkan oleh Fuller adalah Moralitas sebagai tujuan dan landasan dari adanya hukum. Keberadaan Hukum haruslah sesuai dengan moralitas, dan moralitas tidak bisa dilepaskan dari hukum.

\section{KESIMPULAN DAN SARAN}

Perdebatan kedua pemikir ini lantas membawa pemahaman yang luas terhadap pemahaman mengenai Hukum. Setidaknya hampir dalam abad ke-21 ini pemahaman ini masi menjadi perbincangan hangat terlebih kritik-kritik pemikiran mereka. Banyak pemikir dengan disiplin ilmu lain kemudian mengangkat pemikiran hingga sejarah ini seperti; sejarawan hukum, filsuf hukum analitik, sarjana hukum internasional, penteori hukum dan sastra, pluralis hukum, sarjana hukum pidana, bersimpati kepada Hart dan Fuller.

Hingga saat ini hubungan antara hukum dan moralitas secara umum termasuk perdebatan antara Hart dan Fuller keberagaman perspektif yang akan membantu banyak dalam hal berpikir melalui perdebatan dari berbagai sudut pandang dan disiplin ilmu, khususnya Ilmu Hukum. Kenyataan-kenyataan di dunia nyata juga kerap kali terus memperdebatkan dua filsafat besar ini dimana terdapat hukum yang perlu moral dan moral yang perlu dipisahkan dari hukum untuk bisa menjalankan hukum itu secara lurus menurut para pengikutnya.

\section{REFERENSI}

Strauss, Leo. 1968. "Natural Law" Encyclopedia of the Social Sciences. Macmillan.

Rommen, Heirinc A. 1947. "The Natural Law: A Study in Legal and Social Philosophy Trans".

Hart, H. L. A. (1958). "Positivism and the Separation of Law and Morals". Harvard Law Review. 71 (4): 593-629.

Fuller, Lon L. (1958). "Positivism and Fidelity to Law- A Reply to Professor Hart". Harvard Law Review. 71 (4): 630-672.

\footnotetext{
${ }^{11}$ Fuller, Lon L, ibid, 630-672.
} 


\section{Competing interests}

No conflict interest.

\section{Funding.}

None.

\section{Acknowledgements.}

Thank you to all those who have supported and helped this research.

\section{About the Authors}

The author is a researcher at Parliament Republic of Indonesia 